\title{
FACTORS ASSOCIATED WITH THALASSAEMIA CARRIER AMONG FORM FOUR STUDENTS IN KEDAH, MALAYSIA
}

\author{
Rosidah Omar ${ }^{1}$, Norizan Ahmad ${ }^{1}$ and Ngee Wen Sze ${ }^{1}$ \\ ${ }^{1}$ Family Health Unit, Kedah State Health Department, Ministry of Health Malaysia, Simpang Kuala, Jalan Kuala Kedah, \\ 05400 Alor Setar, Kedah, Malaysia
}

Corresponding author: Rosidah Omar

Email: rosidahomar87@gmail.com

\begin{abstract}
Thalassaemia and abnormal haemoglobins are the most common genetic disorder worldwide. School-based screening thalassaemia program for form four students was introduced with the objective to screen for the thalassaemia status. There is paucity in the data in Kedah on distribution of thalassaemia carrier and the associated factors. Hence this study aims to identify the factors associated with being a thalassaemia carrier and to describe the laboratory cost for the thalassaemia screening. This study used secondary data from the school-based thalassaemia screening in 2018 obtained from Kedah State Health Department. Results showed the prevalence of thalassaemia carrier among form four students in Kedah was $10.91 \%$. Multivariate logistic regression showed that students from Baling, Padang Terap and Yan were 1.40, 1.34 and 1.23 times more likely to be a thalassaemia carrier respectively compared to Kota Setar (aOR Baling 1.40;95\% Cl 1.21,1.64; aOR Padang Terap 1.34;95\% Cl 1.11,1.61 and aOR Yan 1.23;95\% Cl 1.03,1.47). Malay and Siamese students were five times more likely be thalassaemia carriers compared to Indian (aOR Malay $5.16 ; 95 \% \mathrm{Cl}$ 3.42,7.79, aOR Siamese 5.63;95\% CI 3.19,9.97). Meanwhile, Chinese students had 2.61 higher odds to be a thalassaemia carrier compared to Indian (aOR Chinese $2.61 ; 95 \% \mathrm{Cl} 1.65,4.12)$. The laboratory cost for the thalassaemia screening ranged from RM2.14 to RM142.14 per participant. As for conclusion, this study reported high prevalence (10.91\%) of thalassaemia carriers in Kedah. Our study also confirmed that the district and the ethnicity significantly influenced the thalassaemia carrier status. The identified factors should inform future thalassaemia campaign to prevent higher prevalence of thalassaemia patients.
\end{abstract}

Keywords: Thalassaemia carrier, school-based screening, prevalence, factors.

\section{INTRODUCTION}

Thalassaemia and abnormal haemoglobins are the most common genetic disorder worldwide. The defective genes can be inherited from either parent. There are two main types of thalassaemia, alpha and beta. It can manifest as thalassaemia major (patient) or minor (carrier) ${ }^{1}$. Patient with thalassaemia major require lifelong blood transfusion and long term monitoring for the treatment side effects ${ }^{2}$. Although being a carrier of thalassaemia trait has no adverse health effect, if a carrier has a child with another carrier, every pregnancy will have a $25 \%$ risk of producing a thalassaemia major child, $50 \%$ risk of producing thalassaemia carrier/ minor and 25\% risk producing a normal child ${ }^{1}$. Looking at the high morbidity and mortality related to transfusiondependent thalassaemia, the World Health Organization (WHO) recommended a comprehensive strategy which include prevention through community information, carrier screening and counselling ${ }^{1}$.

\section{Thalassaemia in Malaysia}

In Malaysia, thalassaemia is the most common inherited blood disorder. There is an estimated number of 120-350 new-born with thalassaemia major every year ${ }^{3}$. According to Malaysia Thalassaemia Registry, as of $28^{\text {th }}$ November 2018, there have been as many as 8681 thalassaemia patients registered in the registry 4 . Out of which, Sabah showed the largest number of registered thalassaemia cases in Malaysia, with a total of 1814 patients $(22.72 \%)^{4}$. This is followed by Selangor with 1169 patients (14.64\%) and Kedah with 694 patients $(8.69 \%)^{4}$.

\section{Thalassaemia in Kedah}

As of 2018, Kedah has been reported as being the third-highest state with registered thalassaemia patient with 694 patients $(8.69 \%)^{4}$. The most common type of thalassaemia in Kedah is $\mathrm{HbE}$ beta thalassaemia, involving 290 patients $(41.79 \%)^{4}$. There were 31 deaths of thalassaemia patient in Kedah (2007 till 2018) ${ }^{4}$.The most common cause of death among thalassaemia in Kedah patients was infections ${ }^{4}$. Meanwhile, Mohamed et al. in 2017 conducted a study looking at thalassaemia carrier rate in Kedah and found that the prevalence of thalassaemia carrier among form four students was $9.13 \%^{5}$.

Due to the high disease burden, Ministry of Health Malaysia introduced the thalassaemia prevention and control program with the aim to reduce morbidity and mortality among thalassaemia patients. In 2016, school-based screening thalassaemia program for form four students (aged 16 years old) was introduced to screen for thalassaemia status ${ }^{1}$. Identifying the status of thalassaemia carrier is essential to prevent a 
carrier from having a child with another carrier. Besides, determining the factors associated with thalassaemia carrier is critical for planning of future targeted interventional programmes. Nevertheless, there is paucity of data in Kedah on the determining factors associated with thalassaemia carrier. Hence, this study is aimed to determine the distribution of thalassaemia carriers among form four students in Kedah and to identify the factors associated with being a thalassaemia carrier. This study will also describe the laboratory cost for the thalassaemia screening. The identified factors will provide a window of opportunity in planning future targeted intervention activities. Ultimately, with the optimisation of the thalassaemia screening and counselling programmes, thalassaemia could be a preventable disease in the future.

\section{METHODS}

\section{Study Design and Data Source}

The study employed a cross-sectional design. In this study, eligible participants were form four students (aged 16 years old) from public secondary schools in Kedah registered under the Ministry of Education Malaysia. Students whose parent refused to give consent, non-Malaysian, known case of thalassaemia, private and boarding schools were excluded from the study. There were 202 (94.39\%) public secondary and 12 (5.61\%) private secondary schools in Kedah registered under the Ministry of Education Malaysia6 ${ }^{6}$ In 2018, out of the 202 public secondary schools, only 125 schools (61.88\%) participated in the thalassaemia screening program among form four students involving 25599 students. Out of which, 21603 (84.39\%) were Malay, 2164 (8.45\%) were Chinese, 1565 were Indian (6.11\%), 258 (1.01\%) were Siamese and $9(0.04 \%)$ were others.

This study used offline data collection via database from the school-based thalassaemia screening in 2018 that was obtained from the Family Health Unit, Kedah State Health Department. The data was contributed by the school health teams from eleven districts in Kedah from $1^{\text {st }}$ January 2018 until 31 $1^{\text {st }}$ December 2018. Data collection time for this study was in March 2020. Information such as gender, ethnicity, district and types of thalassaemia carrier were sent to Kedah State Health Department on a monthly basis.

\section{Statistical analysis}

Descriptive statistics were used to describe the sociodemographic characteristics of the study participants. The prevalence of thalassaemia carrier was reported as a percentage. Comparisons between thalassaemia carriers and non-carriers were performed using chi-square or Fisher exact tests for categorical data. Factors associated with the thalassaemia carrier were evaluated using multivariate analysis. The statistical significance was set at $p<0.05$. All analyses were performed using STATA version 14.0 (serial number 301406227318). The cost for laboratory testing were obtained from the hospital's account department.

\section{Ethics}

Research ethical approval was obtained from the Medical Research \& Ethics Committee of the Malaysian Ministry of Health (NMRR-20-625-54390 (IIR)).

\section{RESULTS}

In 2018, a total of 22838 form four students in Kedah consented to participate in Thalassaemia screening program. However, only 19719 (86.34\%) students had complete test results and were further analyzed. The participants were predominantly female (53.92\%) and Malay (84.67\%). The participants were from District of Kuala Muda (19.51\%), Kulim (18.21\%), Kota Setar (16.28\%), Kubang Pasu (9.65\%), Baling (8.20\%), Pendang (6.37\%), Yan (6.08\%), Padang Terap (5.07\%), Langkawi (4.81\%), Sik (3.29\%) and Bandar Baharu (2.53\%).

In this study, the prevalence of Thalassaemia carriers among form four students in Kedah was $10.91 \%$. Table 1 shows the sociodemographic characteristics according to the status of thalassaemia carrier. Crude analysis showed that there was an association between ethnicity, districts and thalassaemia carrier status $(p<0.001)$. However, there was no association between gender and thalassaemia carrier status $(p=0.501)$.

Table 2 shows the prevalence and distribution of thalassaemia carrier in Kedah. The results show the high prevalence of alpha Thalassaemia carrier which affect $4.61 \%$ of the total sample taken as compared to other types of thalassaemia carriers. Results also show districts such as Baling (8.28\%), Bandar Baharu (6.43\%), Kota Setar (5.39\%), Kulim (3.29\%), Langkawi (6.12\%) and Sik (6.79\%) are more prevalent with alpha thalassaemia carriers compared to other types of thalassaemia carrier. Meanwhile, districts such as Kuala Muda (4.00\%), Kubang Pasu (4.73\%), Padang Terap (6.91\%), Pendang (4.70\%) and Yan (7.42\%) are more prevalent with $\mathrm{HbE}$ Thalassaemia carriers. To give the results a better understanding, the distributions of thalassaemia carrier in Kedah are mapped in Figure 1. 
Malaysian Journal of Public Health Medicine 2021, Vol. 21 (1): 134-140

Table 1: Sociodemographic Characteristic according to Thalassaemia Carrier Status $(\mathbf{N}=19719)$

\begin{tabular}{|c|c|c|c|c|}
\hline Variable & $\begin{array}{c}\text { Not Carrier } \\
\mathbf{N}(\%) \\
\end{array}$ & $\begin{array}{c}\text { Carrier } \\
\mathbf{N}(\%) \\
\end{array}$ & Overall & $P$ value \\
\hline Gender & & & & $0.501^{a}$ \\
\hline Male & 8110 (46.17) & $977(45.40)$ & 9087 (46.08) & \\
\hline Female & 9457 (53.83) & $1175(54.60)$ & 10632 (53.92) & \\
\hline Ethnicity & & & & $<0.001^{b}$ \\
\hline Malay & $14690(83.63)$ & 2005 (93.16) & 16695 (84.67) & \\
\hline Chinese & $1559(8.87)$ & $94(4.37)$ & $1653(8.38)$ & \\
\hline Indian & 1137 (6.47) & $24(1.12)$ & 1161 (5.89) & \\
\hline Siamese & $175(1.00)$ & $29(1.35)$ & $204(1.03)$ & \\
\hline Bumiputra Sabah & $4(0.02)$ & $0(0.00)$ & $4(0.02)$ & \\
\hline Bumiputra Sarawak & $2(0.01)$ & $0(0.00)$ & $2(0.01)$ & \\
\hline District & & & & $<0.001^{a}$ \\
\hline Baling & $1357(7.72)$ & $261(12.14)$ & $1618(8.20)$ & \\
\hline Bandar Baharu & $433(2.47)$ & $65(3.02)$ & $498(2.53)$ & \\
\hline Kota Setar & $2835(16.14)$ & 376 (17.47) & $3211(16.28)$ & \\
\hline Kuala Muda & $3526(20.07)$ & $321(14.92)$ & 3847 (19.51) & \\
\hline Kubang Pasu & $1704(9.70)$ & $200(9.29)$ & $1904(9.65)$ & \\
\hline Kulim & 3343 (19.03) & $248(11.52)$ & 3591 (18.21) & \\
\hline Langkawi & $828(4.72)$ & $120(5.58)$ & $948(4.81)$ & \\
\hline Padang Terap & $839(4.78)$ & $160(7.43)$ & 999 (5.07) & \\
\hline Pendang & $1118(6.36)$ & $138(6.41)$ & $1256(6.37)$ & \\
\hline Sik & $561(3.19)$ & $87(4.04)$ & $648(3.29)$ & \\
\hline Yan & $1023(5.82)$ & $176(8.18)$ & $1199(6.08)$ & \\
\hline
\end{tabular}

${ }^{a}$ Chi square test was performed

${ }^{b}$ Fisher exact test was performed because the number in some cells were lower than five

Table 2: Distribution of Thalassaemia Carrier in Kedah

\begin{tabular}{lccccc}
\hline \multicolumn{1}{c}{ District } & $\begin{array}{c}\text { Not carrier } \\
\mathbf{N}(\%)\end{array}$ & $\begin{array}{c}\text { Alpha } \\
\text { Thalassaemia } \\
\text { Carrier } \\
\mathbf{N}(\%)\end{array}$ & $\begin{array}{c}\text { HbE } \\
\text { Thalassaemia } \\
\text { Carrier } \\
\mathbf{N}(\%)\end{array}$ & $\begin{array}{c}\text { Beta } \\
\text { Thalassaemia } \\
\text { Carrier } \\
\mathbf{N}(\%)\end{array}$ & $\begin{array}{c}\text { Other } \\
\text { Haemoglobinopathy } \\
\text { N (\%) }\end{array}$ \\
\hline Baling & $1357(83.87)$ & $134(8.28)$ & $100(6.18)$ & $26(1.61)$ & $1(0.06)$ \\
Bandar Baru & $433(86.95)$ & $32(6.43)$ & $26(5.22)$ & $5(1.00)$ & $2(0.40)$ \\
Kota Setar & $2835(88.29)$ & $173(5.39)$ & $140(4.36)$ & $52(1.62)$ & $11(0.34)$ \\
Kuala Muda & $3526(91.66)$ & $100(2.60)$ & $154(4.00)$ & $65(1.69)$ & $2(0.06)$ \\
Kubang Pasu & $1704(89.49)$ & $78(4.10)$ & $90(4.73)$ & $30(1.57)$ & $2(0.11)$ \\
Kulim & $3343(93.09)$ & $118(3.29)$ & $101(2.81)$ & $27(0.75)$ & $2(0.06)$ \\
Langkawi & $828(87.34)$ & $58(6.12)$ & $43(4.54)$ & $19(2.00)$ & $0(0.00)$ \\
Padang Terap & $839(83.98)$ & $66(6.61)$ & $69(6.91)$ & $23(2.30)$ & $2(0.20)$ \\
Pendang & $1118(89.01)$ & $48(3.82)$ & $59(4.70)$ & $26(2.07)$ & $5(0.40)$ \\
Sik & $561(86.57)$ & $44(6.79)$ & $34(5.25)$ & $9(1.39)$ & $0(0.00)$ \\
Yan & $1023(85.32)$ & $59(4.92)$ & $89(7.42)$ & $24(2.00)$ & $4(0.34)$ \\
Total & $17567(89.09)$ & $910(4.61)$ & $905(4.59)$ & $306(1.55)$ & $31(0.16)$ \\
\hline
\end{tabular}

Table 3 shows the result of the univariate logistic regression that was applied to sociodemographic characteristics and the status of thalassaemia carrier. It was evident from the table, students from Baling (OR 1.42; 95\% Cl 1.19, 1.67), Padang Terap (OR 1.34; 95\% Cl 1.10, 1.65) and Yan (OR $1.23 ; 95 \% \mathrm{Cl} 1.02,1.50$ ) had significant higher odds to be thalassaemia carriers compared to Kota Setar. Kota Setar district was the selected reference group due to its central location in Kedah. Meanwhile, districts such as Kuala Muda
(OR 0.79; 95\% Cl 0.68, 0.93) and Kulim (OR 0.64; $95 \% \mathrm{Cl} 0.54,0.76)$ had lower odds as compared to Kota Setar to be Thalassaemia carriers. With regards to ethnicity, Malay $(\mathrm{OR} 5.14 ; 95 \% \mathrm{Cl} 3.41$, 7.76), Chinese (OR 2.61; 95\% Cl 1.65, 4.11) and Siamese (OR 5.80, 95\% Cl 1.27, 10.27) had higher odds to be thalassaemia carriers as compared to Indian. Indian was the selected reference group in view of its lowest number of thalassaemia carrier students in this study. 
In this study, we also performed a multivariate logistic regression to determine the factors associated with the thalassaemia carrier status. As illustrated in Table 4 the fully adjusted model depicted that students from Baling were 1.4 times more likely to be thalassaemia carriers compared to Kota Setar (aOR $1.40 ; 95 \% \mathrm{Cl} 1.21,1.64)$. In addition, it also showed that students from Padang Terap and Yan were 1.34 and 1.23 times more likely to be thalassaemia carriers respectively compared to Kota Setar (aOR Padang Terap 1.34; 95\% Cl 1.11, 1.61 and aOR Yan 1.23; $95 \% \mathrm{Cl} 1.03,1.47)$. In contrast, students from
Kuala Muda and Kulim were less likely to be a thalassaemia carrier as compared to Kota Setar (aOR Kuala Muda 0.79; 95\% Cl 0.69, 0.91, aOR Kulim 0.63; 95\%Cl 0.55,0.74).

With regards to ethnicity, the model also revealed that Malay and Siamese students were five times more likely to be thalassaemia carriers compared to Indian (aOR Malay 5.16; 95\% $\mathrm{Cl} 3.42,7.79$, aOR Siamese 5.63; 95\% Cl 3.19, 9.97). Lastly, the model depicted that Chinese students had 2.61 higher odds to be thalassaemia carriers compared to Indians (aOR Chinese 2.61; 95\% Cl 1.65, 4.12).

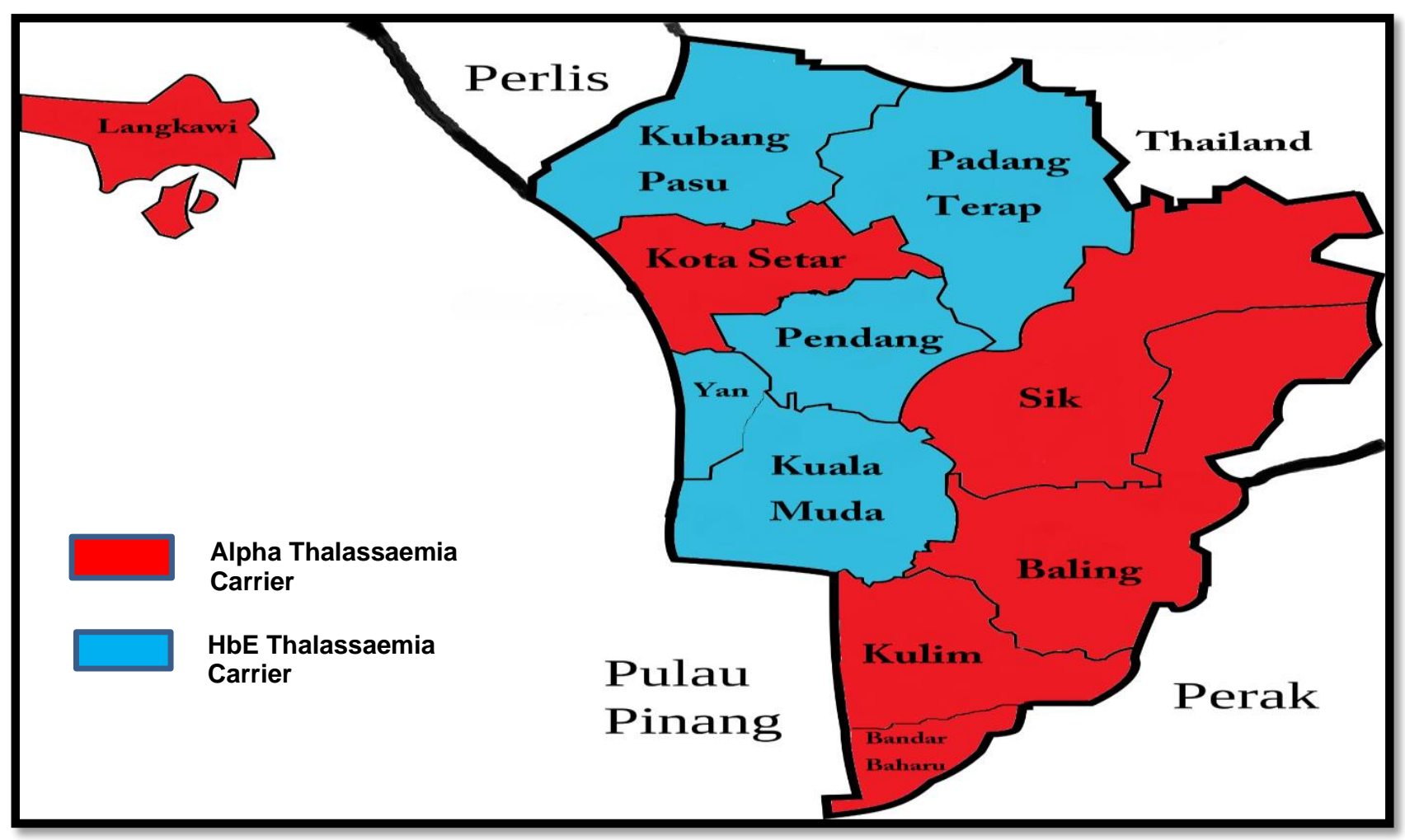

Figure 1: Distribution of Thalassaemia Carrier among Form 4 Students in Kedah according to District

Table 5 shows the final model of the factors associated with thalassaemia carrier in Kedah. Based on the final model, it was observed that eight variables were significant factors associated with thalassaemia carrier namely, students from Baling, Kuala Muda, Kulim, Padang Terap, Yan, and of Malay, Chinese and Siamese ethnicity. In this study, the methods used to evaluate the goodness model of fit for the logistic model included the Hosmer and Lemeshow test, classification table and receiver operating characteristic (ROC) curve analysis. The Hosmer Lemeshow goodness of fit test was applied to the final model and gave a result of $p=0.7927$, which indicated that the model was a good fit. The model also correctly classified $89.00 \%$ of the respondents and it was considered as an excellent discrimination. However, the area under the curve for the model in this study was 0.6017 , which meant that the model was able to accurately discriminate only $60.17 \%$ of the cases (figure 2). Nevertheless, two out of the three measures performed to assess the goodness of fit of the model showed that the assumptions for the fitted model were met. We can thus conclude that the final model was accepted.

The main component for the diagnostic test was the full blood count (FBC) which cost RM2.14 per test. Then, students with abnormal FBC were subject for Hemoglobin Analysis and or DNA Analysis which cost RM40.00 and RM 100.00 respectively. Hence, the laboratory cost for the thalassaemia screening ranged from minimum of RM 2.14 to maximum of RM142.14 per student. The analysis for this study shows total diagnostic cost for this thalassaemia screening in Kedah was estimated at RM464 
818.66 in 2018. However, the actual total diagnostic expenditure for the thalassaemia screening in Kedah is expected to be more, in view of this study only accounted for participants with complete test results.

Table 3: Univariate Logistic Regression on Factors Associated with Thalassaemia Carrier in Kedah

\begin{tabular}{|c|c|c|}
\hline Variable & Crude Odd ratio $(95 \% \mathrm{Cl})$ & $p$ value \\
\hline \multicolumn{3}{|l|}{ District } \\
\hline Kota Setar & 1.0 reference & \\
\hline Baling & $1.42(1.19,1.67)$ & $<0.001$ \\
\hline Bandar Baru & $1.13(0.85,1.50)$ & 0.398 \\
\hline Kuala Muda & $0.79(0.68,0.93)$ & 0.004 \\
\hline Kubang Pasu & $0.87(0.73,1.05)$ & 0.151 \\
\hline Kulim & $0.64(0.54,0.76)$ & $<0.001$ \\
\hline Langkawi & $1.07(0.86,1.33)$ & 0.542 \\
\hline Padang Terap & $1.34(1.10,1.65)$ & 0.004 \\
\hline Pendang & $0.89(0.72,1.10)$ & 0.263 \\
\hline Sik & $1.10(0.86,1.41)$ & 0.455 \\
\hline Yan & $1.23(1.02,1.50)$ & 0.029 \\
\hline \multicolumn{3}{|l|}{ Ethnicity } \\
\hline Indian & 1.0 reference & \\
\hline Malay & $5.14(3.41,7.76)$ & $<0.001$ \\
\hline Chinese & $2.61(1.65,4.11)$ & $<0.001$ \\
\hline Siamese & $5.80(1.27,10.27)$ & $<0.001$ \\
\hline Variable & Adjusted Odd Ratio (95\% CI) & D value \\
\hline \multicolumn{3}{|l|}{ District } \\
\hline Kota Setar & 1.0 reference & \\
\hline Baling & $1.40(1.21,1.64)$ & $<0.001$ \\
\hline Kuala Muda & $0.79(0.69,0.91)$ & 0.001 \\
\hline Kubang Pasu & $0.87(0.74,1.02)$ & 0.093 \\
\hline Kulim & $0.63(0.55,0.74)$ & $<0.001$ \\
\hline Padang Terap & $1.34(1.11,1.61)$ & 0.002 \\
\hline Yan & $1.23(1.03,1.47)$ & 0.022 \\
\hline \multicolumn{3}{|l|}{ Ethnicity } \\
\hline Indian & 1.0 reference & \\
\hline Malay & $5.16(3.42,7.79)$ & $<0.001$ \\
\hline Chinese & $2.61(1.65,4.12)$ & $<0.001$ \\
\hline Siamese & $5.63(3.19,9.97)$ & $<0.001$ \\
\hline
\end{tabular}

Table 5: Final Model on Factors Associated with Thalassaemia Carrier in Kedah

\begin{tabular}{lccccc}
\hline \multicolumn{1}{c}{ Variable } & $\begin{array}{c}\text { Regression } \\
\text { coefficient (B) }\end{array}$ & Standard Error & p value & Exp (B) & $95 \%$ Cl \\
\hline District & 0.37 & 0.11 & $<0.001$ & 1.45 & $1.25,1.68$ \\
Baling & -0.21 & 0.06 & 0.002 & 0.81 & $0.71,0.93$ \\
Kuala Muda & -0.42 & 0.05 & $<0.001$ & 0.65 & $0.56,0.76$ \\
Kulim & 0.32 & 0.13 & 0.001 & 1.38 & $1.15,1.65$ \\
Padang Terap & 0.24 & 0.11 & 0.007 & 1.27 & $1.06,1.51$ \\
Yan & & & & & \\
Ethnicity & 1.64 & 1.08 & $<0.001$ & 5.17 & $3.42,7.80$ \\
Malay & 0.96 & 0.69 & $<0.001$ & 2.62 & $1.66,4.13$ \\
Chinese & 1.73 & 1.64 & $<0.001$ & 5.62 & $3.18,9.94$ \\
Siamese & -3.62 & 0.01 & $<0.001$ & 0.03 & $0.02,0.04$ \\
cons & & & & & \\
\hline
\end{tabular}




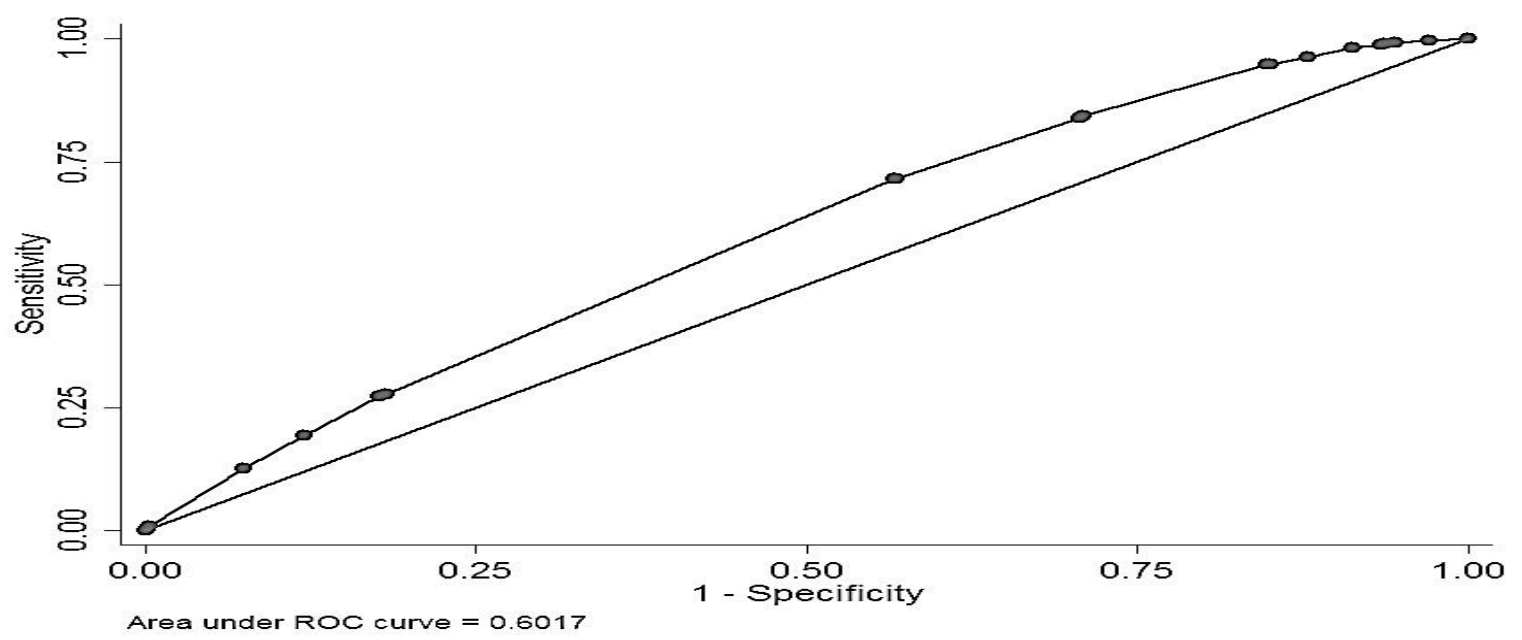

Figure 2: ROC Curve of Factors Associated with Thalassaemia Carrier in Kedah

\section{DISCUSSION}

The aim of this study was to determine the prevalence and distribution of thalassaemia carriers among form 4 students in Kedah and to identify the factors associated with being a thalassaemia carrier. This study also described the laboratory cost for the thalassaemia screening. The result showed the prevalence of Thalassaemia carrier in Kedah was $10.91 \%$. The finding concurred with result reported by Mohamed et al. which the study was also conducted among form four students in Kedah using 2017 data and reported that the prevalence of thalassaemia carriers was $9.13 \%^{5}$. This study demonstrated high prevalence of thalassaemia carriers, mainly alpha Thalassaemia which affect $4.60 \%$ of the total sample taken. This finding was consistent with Mohammad et al. which reported that Kedah had the highest prevalence of alpha thalassaemia carriers of $3.40 \%$ in $2017^{3}$. Districts such as Baling, Bandar Baharu, Kota Setar, Kulim, Langkawi and Sik revealed higher prevalence of alpha thalassaemia carrier compared to other types of thalassaemia carriers. Meanwhile, districts such as Kuala Muda, Kubang Pasu, Padang Terap, Pendang and Yan were more prevalent in HbE Thalassaemia carriers.

This study also confirmed the thalassaemia carrier status was significantly associated with district and ethnicity. We found that students from Baling, Padang Terap and Yan were more likely to be Thalassaemia carriers than students from Kota Setar. In contrast, students from Kuala Muda and Kulim which located at the southern region of Kedah were less likely to be thalassaemia carrier as compared to students from Kota Setar. To the best of our knowledge this was the first study in Malaysia that described thalassaemia carriers according to geographical regions. This study showed districts that geographically border with the southern part of Thailand such as Baling and Padang Terap had significantly higher odds of thalassaemia carriers. This phenomenon can be explained by the cultural norm in these districts. In these districts, inter-racial marriages with Malay-Kedahans and Siamese from Thailand were common. Since both ethnicities had higher odds of being a thalassaemia sufferer or carrier, there was a higher chance of them having a thalassaemic or thalassaemia carrier child

Interestingly, the distribution of types of thalassaemia carriers in the districts that border with Southern Thailand such as Kubang Pasu and Padang Terap had more HbE thalassaemia carriers. This was consistent with a previous study by Nuinoon et al. in Thailand that reported the high prevalence of $\mathrm{HbE}$ trait in the southern area at the junction between Thailand and Malaysia at $12.10 \%{ }^{7}$. Although the district of Pendang was centrally located in Kedah, but sociodemographically, the Siamese ethnic group was the second largest population constituting $9.00 \%$ of the total population ${ }^{8}$. Unsurprisingly, Pendang was also prevalent with $\mathrm{HbE}$ thalassaemia carriers. Another interesting finding in this study was that the Malay and Siamese were five times more likely to be thalassaemia carrier than Indian. To the best of our knowledge, this was the first study in Peninsular Malaysia that reported that ethnicity had significant influence on thalassaemia carriers.

The study demonstrated that targeted screening among school children was beneficial in screening for thalassaemia status among adolescent. This was very important to provide information regarding thalassaemia in order to make an informed decision when choosing a future partner. Knowing one's own thalassaemia status could help in preventing future delivery of a thalassaemia major baby. The results of the study could assist in delivery of genetic counselling and the need of providing appropriate treatment when necessary. Furthermore, the aboveidentified factors will inform future thalassaemia 
campaign in Kedah and be used in the development of targeted intervention programmes to prevent an increase in patients with thalassaemia major.

In this study, the cost for laboratory testing per student ranged from a minimum of RM 2.14 to maximum of RM142.14. Riewpaiboon et al reported the average annual cost per patient in a study among beta-thalassaemia/HbE and betathalassaemia major in Thai children was USD 950 or RM3639.56 (price year 2019) ${ }^{9}$. In view of high economic burden in managing thalassaemia major patient, we can conclude that the screening and preventing future delivery of a thalassaemia major baby was cost saving. Hence this screening program should be continued to help in identifying the thalassaemia carrier patient.

However, this study was not without limitations. First, the findings confirmed that the thalassaemia carrier status was significantly associated with sociodemographic factors of Kedah hence the results cannot be generalized to other state in Malaysia. Second, this study was a cross-sectional study, hence causal relationship could not be inferred. Finally, this study may have not captured other predictors of thalassaemia carrier status such as consanguineous marriage and family history of thalassaemia.

\section{CONCLUSION}

In conclusion, our study reported high prevalence (10.91\%) of thalassaemia carriers among form four students in Kedah. Our study confirmed that the district and ethnicity were significantly influence thalassaemia carrier status. The identified factors should be used to inform future thalassaemia campaigns and in the development of targeted intervention programmes to prevent higher prevalence of thalassaemia patients. We believed the implementation of thalassaemia screening program among form four school children in Kedah was successful. Therefore, continuous efforts should be taken to sustain this programme.

\section{ACKNOWLEDGMENTS}

The authors would like to thank the Director General of Health Malaysia for his permission to publish this article. We would also like to thank the Kedah State Health Department for the administrative support.

\section{REFERENCES}

1. Ministry of Health Malaysia. Guidelines on the National Thalassaemia Screening Programme in Malaysia. Division of Family Health Development. Ministry of Health Malaysia 2009:1-29.

2. Ministry of Health Malaysia. Clinical Practice Guideline on the Management of Transfusion Dependent Thalassaemia. Division of Medical Development. Ministry of Health Malaysia 2009: 13-31

3. Ismail A, Campbell MJ, Ibrahim HM, et al. Health related quality of life in Malaysian children with thalassaemia. Health Qual Life Outcomes 2006; 4:39.

4. Ibrahim HM, eds. Malaysian Thalassaemia Registry Report 2018. Division of Medical Development. Ministry of Health Malaysia 2019.

5. Mohamed DI, Nordin NS, Daud MS, et al. Mapping of Thalassemia Carriers in Sabah and Kedah: A Unique Diversity of Thalassaemia Carrier Distribution in Malaysia. Hemoglobin 2019; 43(6):340-340.

6. Ministry of Education Malaysia. https://www.moe.gov.my/pendidikan/pendi dikan-menengah/sekolah-menengahkebangsaan-harian (accessed December 01, 2020)

7. Nuinoon $M$, Kruachan $K$, Sengking $W$, et al. Thalassemia and Hemoglobin $E$ in Southern Thai Blood Donors. Adv Hematol 2014; 2014:1-6.

8. Safikah N. Latar Belakang Daerah Pendang. 2015.

https: / /www.academia.edu/31826330/LATA R_BELAKANG_DAERAH_PENDANG (accessed Feb 08, 2020)

9. Riewpaiboon A, Nuchprayoon I, Torcharus K, et al. Economic burden of betathalassemia/HbE and beta-thalassemia major in Thai children. BMC Research Notes 2010; 3 (29): 1-7 